\title{
Effects of the ice popsicle on vasopressin, osmolality, thirst intensity, and thirst discomfort
}

\author{
Efeitos do picolé de gelo sobre vasopressina, osmolaridade, \\ intensidade e desconforto da sede \\ Efectos del picolé de hielo sobre vasopresina, osmolaridad, \\ intensidad y malestar de la sed
}

\section{Thammy Gonçalves Nakaya ${ }^{a}$ Marilia Ferrari Conchon ${ }^{a}$ Aline Korki Arrabal Garcia ${ }^{a}$ Ernane Torres Uchôab Lígia Fahl Fonseca ${ }^{a}$}

\section{How to cite this article:} Nakaya TG, Conchon MF, Garcia AKA, Uchôa ET, Fonseca LF. Effects of ice popsicle on vasopressin, osmolality, thirst intensity, and thirst discomfort. Rev Gaúcha Enferm. 2021;42:e20190449. doi: https://doi.org/10.1590/19831447.2021.20190449 a Universidade Estadual de Londrina (UEL), Programa de Pós-graduação em Enfermagem. Departamento de Enfermagem. Londrina, Paraná, Brasil.

bniversidade Estadual de Londrina (UEL), Programa de Pós-graduação em Ciências Fisiológicas Departamento de Fisiologia. Londrina, Paraná, Brasil.

\section{ABSTRACT}

Objective: To analyze the effects of the ice popsicle on vasopressin, osmolality, thirst intensity, and thirst discomfort. Method: This is a quasi-experimental, pre- and post-test study conducted in a laboratory. The sample consisted of nine healthy male volunteers, who received $2 \%$ hypertonic saline solution.

Results: Popsicle intake did not result in a statistically significant reduction in vasopressin levels ( $F=0.876$ and $p=0.428$ ). However, there was a reduction in the hormonal physiological profile of vasopressin from $7.1 \mathrm{pg} / \mathrm{ml} \mathrm{to} 5.8 \mathrm{pg} / \mathrm{ml}$ after the first two interventions. Osmolality concentration changed from 270.65 to $286.51 \mathrm{~m} 0 \mathrm{sm} / \mathrm{kg}$, with no statistical difference ( $F=2.207 ; p=0.09$ ). Ice popsicles significantly reduced thirst intensity ( $F=10.00 ; p=0.001)$ and thirst discomfort $(F=10.528 ; p<0.001)$.

Conclusion: There was a reduction in thirst intensity and discomfort after the use of the $20 \mathrm{ml}$ ice popsicle. There was no statistical difference for vasopressin and osmolality. However, there was a reduction in the hormonal physiological profile of vasopressin during 30 minutes of intervention.

Keywords: Arginine vasopressin. Osmolar concentration. Thirst. Perioperative nursing.

\section{RESUMO}

Objetivo: Avaliar efeitos do picolé de gelo sobre perfil hormonal de vasopressina, osmolaridade, intensidade e desconforto da sede. Método: Quase-experimental, pré e pós-teste, realizado em laboratório. Nove voluntários saudáveis receberam solução salina endovenosa $2 \%$ e um picolé de gelo $20 \mathrm{ml}$ a cada 15 minutos. As variáveis foram coletadas em cinco momentos.

Resultados: Ingestão do picolé não resultou queda estatisticamente significativa da vasopressina ( $F=0,876$ e $p=0,428$ ). Houve redução no perfil hormonal da vasopressina de $7,1 \mathrm{pg} / \mathrm{ml}$ para $5,8 \mathrm{pg} / \mathrm{ml}$ após duas intervenções. Osmolaridade plasmática alterou de $270,65 \mathrm{para} 286,51 \mathrm{~m} 0 \mathrm{sm} / \mathrm{kg}$, sem diferença estatística $(F=2,207 ; p=0,09)$. Houve redução da intensidade ( $F=10,00$ e $p=0,001)$ e desconforto da sede ( $F=10,528 ; p<0,001)$.

Conclusão: Houve redução na intensidade e desconforto da sede. Não houve diferença estatística para vasopressina e osmolaridade. Observou-se redução no perfil fisiológico da vasopressina durante 30 minutos de intervenção.

Palavras-chave: Arginina vasopressina. Concentração osmolar. Sede. Enfermagem perioperatória.

\section{RESUMEN}

Objetivo: Evaluar los efectos del picolé de hielo sobre el perfil hormonal de la vasopresina, la osmolaridad, y la intensidad y el malestar de la sed.

Método: Estudio casi-experimental pre- y pos-test, realizado en laboratorio. Nueve varones voluntarios sanos recibieron solución salina endovenosa al $2 \%$ y un picolé de hielo de $20 \mathrm{ml}$ cada 15 minutos.

Resultados: Ingerir el picolé no derivó en una caída estadísticamente significativa del nivel de vasopresina ( $F=0,876$ y $p=0,428$ ). Entretanto, se registró una reducción en el perfil hormonal de la vasopresina de $7,1 \mathrm{pg} / \mathrm{ml}$ a $5,8 \mathrm{pg} / \mathrm{ml}$ después de las dos intervenciones. La osmolaridad plasmática se modificó de 270,65 a 286,51 m0sm/kg sin diferencia estadística ( $F=2,207 ; \mathrm{p}=0,09)$. Se registraron reducciones en la intensidad ( $F=10,00$ y $p=0,001)$ y en el malestar de la sed $(F=10,528 ; p<0,001)$.

Conclusión: Se registraron reducciones en la intensidad y el malestar de la sed después de la intervención. No hubo diferencia estadística para la vasopresina y la osmolaridad. De esta manera, se observa la reducción en el perfil fisiológico de la vasopresina durante los 30 minutos de la intervención

Palabras-clave: Arginina vasopresina. Concentración osmolar. Sed. Enfermería perioperatoria. 


\section{口INTRODUCTION}

During water deprivation, desire and search for water trigger a complex neuronal communication in the body, in order to balance homeostasis of cell fluids ${ }^{(1)}$. A 1-2\% increase in plasma osmolality to the detriment of the restriction of liquid intake is sufficient to stimulate the neurohypophysis to release arginine vasopressin (AVP). AVP, also called antidiuretic hormone, has a crucial role in maintaining body water balance in these situations, and thus acts as a parallel mechanism of the neural pathway underlying thirst ${ }^{(2-3)}$.

Body cell fluids are regulated through osmotic pressure between intracellular fluids (ICF) and extracellular fluids (ECF). The balance of solutes, especially of sodium ( $\mathrm{Na}+$ ), between these compartments will determine the degree of hydration. Serum osmolality, i.e., the amount of free solute in a given volume of plasma, and urine osmolality, i.e., the number of particles in a certain volume of urine, allows for the measurement of the body hydromineral regulatory response ${ }^{(2)}$.

This neurohormonal complex leads to thirst, which becomes an stressful factor when patients are unable to quench $i \mathrm{t}^{(4)}$. Paradoxically, it is not the focus of attention of the health professionals, although surgical patients remain fasting for up to 216 hours $^{(5)}$.

Thirst can be quenched by means of two mechanisms. Post-absorptive satiety occurs when an individual drinks a large volume of liquids to correct plasma osmolality ${ }^{(6-7)}$. However, this conduct is contraindicated in many clinical situations ${ }^{(5)}$. Recent findings in sensation physiology propose pre-absorptive satiety as an alternative ${ }^{(1-8)}$. This satiety occurs regardless of water absorption by the gastrointestinal tract, using anticipatory mechanisms such as swallowing, gastric digestion, cognition, and thermoreceptors. Thus, low fluid intake is sufficient to achieve satiety, with no need to correct plasma osmolality ${ }^{(1-2,8)}$.

Cold strategies to quench thirst have been developed and effectively used both in the pre- and post-operative periods with good acceptance by the patients. However, their use is still limited to few institutions. A randomized clinical trial showed that the use of a cold strategy, such as the ice popsicle, is more effective to minimize the intensity of thirst, compared with liquids at room temperature(9). Nonetheless, the assessment of the perception of thirst intensity, although indicating osmolality changes ${ }^{(3,10)}$, is still a subjective measure prone to individual changes resulting from individual's interoception ${ }^{(11)}$.

Therefore, hormonal changes involved in satiety have not been sufficiently evaluated yet. The influence of popsicles on neurohormonal and osmotic changes to reach pre-absorptive satiety of thirst is unknown. Hence, the following question arises: What is the behavior of study variable in view of a low-volume cold strategy? The proposed hypothesis is that consuming an ice popsicle will lead to changes in the hormonal profile and in subjective aspects such as thirst intensity and discomfort.

In view of this gap, it is relevant to assess the effects of the ice popsicle on the hormonal profile of vasopressin, osmolality, thirst intensity, and thirst discomfort. This study is expected to broaden understanding on the physiological principles involved in the effectiveness of the ice popsicle to relieve thirst.

\section{METHOD}

This is a quantitative, quasi-experimental, pre- and posttest study conducted in a nationally renowned clinical analysis laboratory located in southern Brazil.

The study sample consisted of male students volunteers between 18 and 40 years of age who reported to be healthy. The invitation of undergraduate and graduate students who were able to participate in the study was held in the classroom, and then a formal invitation was sent via email. The sample size was based on laboratory studies with volunteers that investigated the association of thirst with serum osmolality and AVP using a sample from four to 12 participants ${ }^{(3)}$. Thus, an intentional sample of nine volunteers was selected.

The exclusion criteria were the following: smoking, alcohol use 24 hours before exam collection, nausea, vomiting, and diarrhea for at least one week before the study was performed. The female gender was considered a study exclusion criterion, due to hormonal changes resulting from the menstrual cycle and to the use of contraceptive methods that interfere in the regulation of body fluids.

The Verbal Numerical Scale (VNS) was used to measure thirst intensity. The scale presents a score from zero to ten, with zero representing absence of thirst and ten the most intense thirst the volunteer has ever experienced ${ }^{(12)}$.

The Perioperative Thirst Discomfort Scale (PTDS) was administered to measure thirst discomfort. The scale assesses seven attributes: dry mouth, dry lips, thick tongue, thick saliva, dry throat, bad taste, and desire to drink. The volunteers classify the described attributes into: not uncomfortable at all, a little uncomfortable, or very uncomfortable. The PTDS scores range from zero to 14 , with higher values meaning greater discomfort. This scale has a content validity index of 0.98 , and an internal consistency of 0.91, according to Cronbach's alpha coefficient ${ }^{(13)}$.

Ice popsicles were made using a specific mold and had a predetermined volume of $20 \mathrm{ml}$. In order to mimic in the laboratory, the thirst management protocol as it is followed 
in the clinical practice at the anesthetic recovery room, popsicles were provided to the volunteers three times with 15-minute intervals ${ }^{(9)}$.

Prior to data collection, a pamphlet was sent with instructions and guidelines on preparation before data collection. These instructed the volunteers to fast from food and liquids for 12 hours; not to brush their teeth and not to use mouthwash in the morning of exam collection (to prevent interference of oropharyngeal stimulation from water and menthol during brushing); to discard urine immediately after waking up in the morning; to abstain from alcohol for 24 hours before the exam, and not to practice any physical exercise 60 minutes before undergoing the protocol. All these instructions were reinforced by cell phone text messages sent on the evening before data collection.

Two pilot tests were performed to adjust the proposed method. Initially, the thirst induction method chosen was the infusion of $5 \%$ hypertonic saline solution, for it is a method reported in the literature ${ }^{(3)}$. However, during the procedure, the volunteer presented major discomfort at the venipuncture site, with phlogistic signs. For the second pilot test, the hypertonic saline concentration was reduced to $2 \%$, with no adverse events. The subjects who participated in the pilot tests did not make up the final study sample.

The data collection period occurred from March to May 2018. Prior to the administration of the protocol, the volunteers signed the Free and Informed Consent Form (FICF), and information about name, age, and body weight was collected.

Both the 12-hour fasting and the hypertonic saline infusion aimed to intensify the increase in plasma osmolality. Body weight was used to calculate the volume of hypertonic saline solution to be infused in each volunteer, considering the protocol of $0.06 \mathrm{ml} / \mathrm{kg} / \mathrm{min}$. Therefore, the total volume of saline solution infused was individualized, based on each volunteer's weight. Saline concentration and duration of intravenous infusion were standardized at $2 \%$ and 2 hours, respectively. The solution was prescribed by a physician collaborating with the research group.

On the day scheduled for collection, the volunteers were admitted to the clinical analysis laboratory at 7.30 a.m., were accommodated in armchairs, and had their blood pressure (BP) and heart rate (HR) measured. Two venous accesses were obtained for collection of samples and saline infusion.
Thirst intensity and discomfort were initially measured before saline infusion by a previously trained researcher nurse, using the VNS and the PTDS. In parallel, blood and urine samples were collected to assess AVP and serum and urine osmolality (Moment 1 -M1).

A 2\% hypertonic saline solution was infused during two hours. The vital signs of the volunteers were evaluated every 15 minutes to detect possible changes in $\mathrm{BP}$ and $\mathrm{HR}$, which were not observed in any of the participants. After two hours of infusion, thirst intensity and discomfort were measured again, and blood samples were collected by the laboratory

technicians to assess AVP and serum osmolality (Moment 2 - M2). Immediately after blood was collected, the volunteers received the first ice popsicle, and the procedure was repeated after 15 minutes (Moment 3 - M3), 30 minutes (Moment 4 - M4), and 45 minutes (Moment 5 - M5) (FIGURE 1). Figure 1 shows the protocol used for the development of the present research.

The blood AVP samples were stored in blood collection tubes containing ethylenediaminetetraacetic acid, and the serum osmolality samples were stored in tubes with separating gel. The tubes were identified with volunteer's personal data and collection time, and were then referred to the laboratory. The AVP samples were subsequently referred to a specialized laboratory for hormone analysis. The results were accessed on the websites of the laboratories.

Data processing and analysis were conducted using an Excel $2010^{\circledR}$ spreadsheet, and statistical analyses were conducted using the IBM SPSS ${ }^{\oplus}$ software, version 20.0. Data normality was examined using the Shapiro-Wilk test. Urine osmolality was assessed using the Student's t-test for dependent samples. The AVP, serum osmolality, thirst intensity, and thirst discomfort variables were analyzed using analysis of variance (ANOVA) for repeated measures. In case any statistical difference was detected, Fisher's post-hoc LSD test was conducted. Data sphericity was evaluated using Mauchly's test, and Greenhouse-Geisser correction was used when this assumption was violated. The significance level established was set at $p<0.05$.

In compliance with Resolution No. 466/12 of the National Health Council, the project was submitted to the Ethics Committee on Research with Human Beings of the State University of Londrina and was approved under CAAE 79283417.1.0000.5231. 


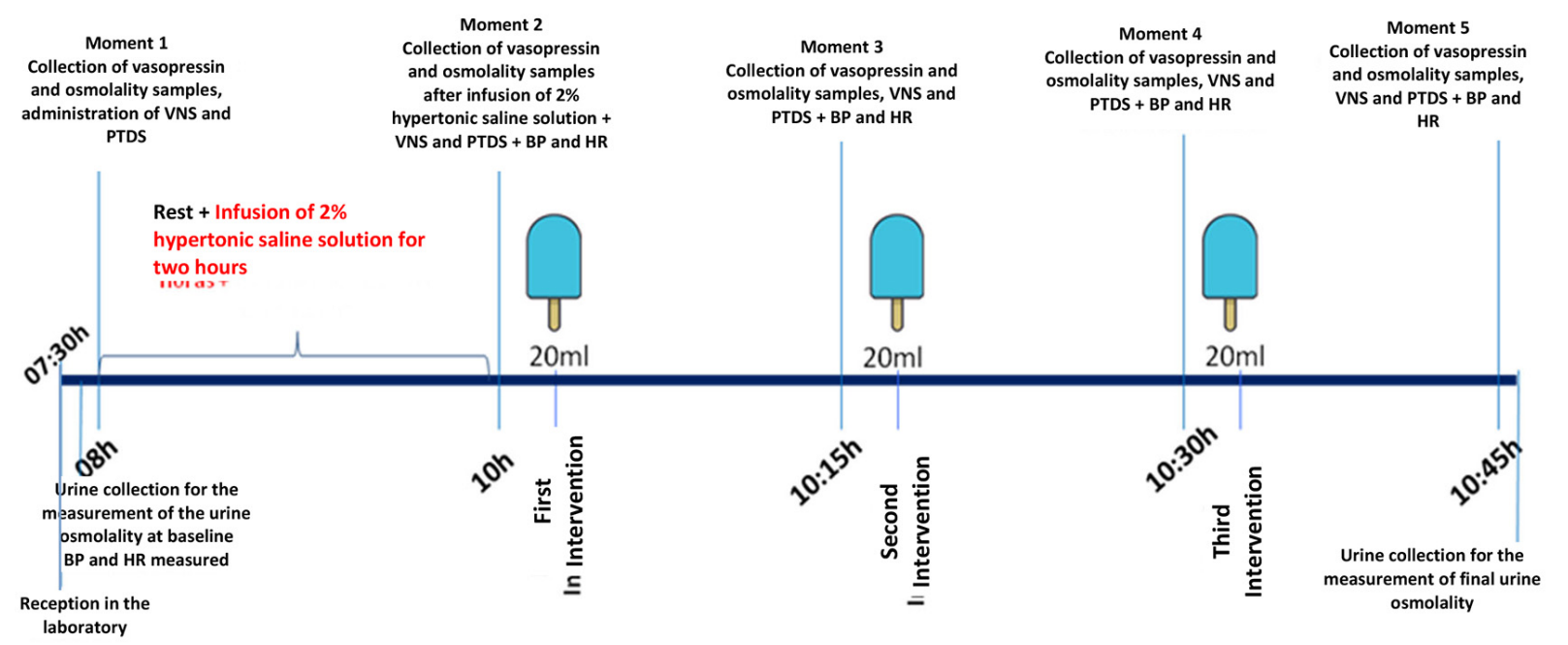

Figure 1 - Follow-up protocol for data collection, Londrina, state of Paraná, Brazil, 2018 Source: The authors.

\section{RESULTS}

Nine healthy volunteers were subjected to the research protocol. The 12-hour fasting was well tolerated by the participants, as well as the intravenous infusion of $2 \%$ hypertonic saline solution. The mean body weight of the volunteers was $79.7 \mathrm{~kg} \pm 9.58$, and their mean age was $25.7 \pm 5.35$ years old.

Graph 1 shows the behavior of the osmolality and vasopressin variables.

There was no significant difference between the moments for the AVP variable ( $F=0.876$ and $p=0.428$ ). However, these values were observed to oscillate over time (Graph 1). Baseline AVP (M1) of $5.90 \mathrm{pg} / \mathrm{ml} \pm 2.90$ increased to $7.12 \mathrm{pg} /$ $\mathrm{ml} \pm 3.59$ after thirst induction with $2 \%$ hypertonic saline solution (M2), in parallel with an increase in plasma osmolality.

Between $\mathrm{M} 2$ and $\mathrm{M} 3$, the volunteers received the first ice popsicle, which led to a decrease in AVP to $6.41 \mathrm{pg} /$ $\mathrm{ml} \pm 2.61$ (M3). This accounts for a 10\% decrease in the hormone concentration of circulating AVP. Graph 1 shows that, in this moment, the osmolality and AVP variables presented inverse trends (osmolality increased while AVP decreased).

This decrease in AVP persisted at M4, when it decreased to $5.80 \mathrm{pg} / \mathrm{ml} \pm 2.68$, equivalent to a $9.51 \%$ decrease in AVP concentration. Overall, there was a $19.51 \%$ decrease compared to post-infusion M2. At M5, AVP increased again to $6.63 \mathrm{pg} / \mathrm{ml} \pm 3.73$, and serum osmolality had the greatest increase in concentration since the beginning of the protocol, reaching $286.51 \mathrm{mOsm} / \mathrm{kg}$.

The 12-hour fasting (M1) and the infusion of 2\% hypertonic saline solution (M2) increased blood osmolality from $270.65 \mathrm{mOsm} / \mathrm{kg}$ (M1) to $286.51 \mathrm{mOsm} / \mathrm{kg}$ (M5) (Graph 1).
However, there was no statistically significant difference ( $F=2.207$ and $p=0.09$ ) between the moments. Thirst induction increased serum osmolality, with a variation of $15.86 \mathrm{mOsm} / \mathrm{kg}$. In relation to the mean urine osmolality at baseline, its value was $948.33 \mathrm{mOsm} / \mathrm{kg}$ (M1). After the experiment (M5), it decreased to $819.44 \mathrm{mOsm} / \mathrm{kg}$.

Graph 2 shows the behavior of the thirst intensity and thirst discomfort variables during the entire protocol.

After thirst was induced by 12-hour fasting (M1), the volunteers reported a mean thirst intensity of $5.33 \pm 3.08$, and a mean thirst discomfort of $6.22 \pm 3.34$. After the participants received the $2 \%$ hypertonic saline solution, the mean thirst intensity increased to $6.00 \pm 3.60$, and thirst discomfort increased to $7.00 \pm 4.03$ (M2).

After the volunteers received the first, second, and third intervention, the mean thirst intensity decreased to $4.00 \pm 3.04$, $2.89 \pm 1.96$, and $2.33 \pm 1.80$ at M3, M4, and M5, respectively. There was a statistically significant difference in thirst intensity between these moments ( $F=10.00$ and $P=0.001$ ).

The mean thirst discomfort at M3, M4, and M5 decreased to $3.78 \pm 2.68,3.22 \pm 3.23$, and $2.11 \pm 2.47$, respectively. There was a statistical difference in thirst discomfort between these moments ( $F=10.528 ; P<0.001)$.

Statistical differences in thirst intensity and thirst discomfort between moments were identified using Fisher's posthoc LSD test. There was a significant difference between M1 and $\mathrm{M} 4$, and between $\mathrm{M} 1$ and $\mathrm{M} 5$. At the end of the infusion, there was a significant difference between $\mathrm{M} 2$ and $\mathrm{M} 3, \mathrm{M} 2$ and M4, and between $\mathrm{M} 2$ and M5.

This study presented a moderate positive Pearson correlation ( $r=0.68$ and $p=0.04$ ) between thirst intensity and 


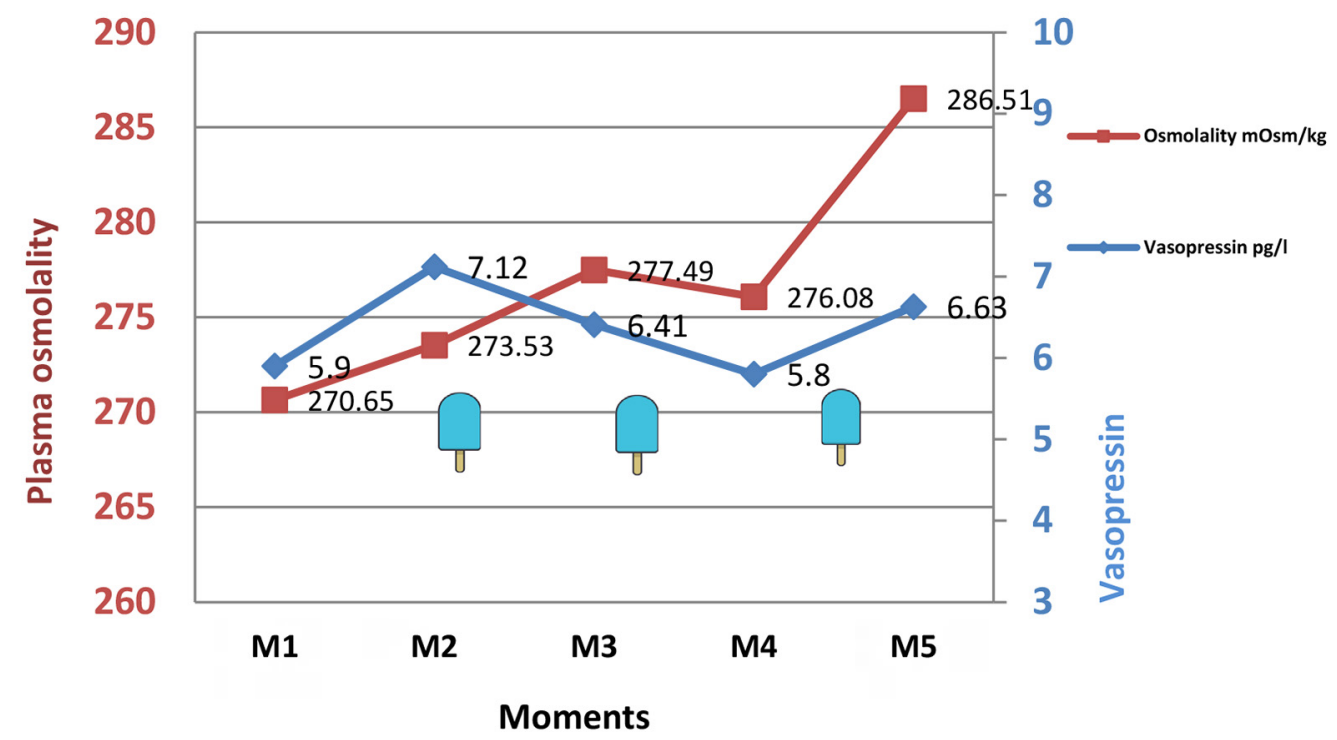

Graph 1 - Variation of the mean serum osmolality and plasma vasopressin during the five assessment moments of the protocol; Londrina, state of Paraná, Brazil, 2018 Source: The authors.

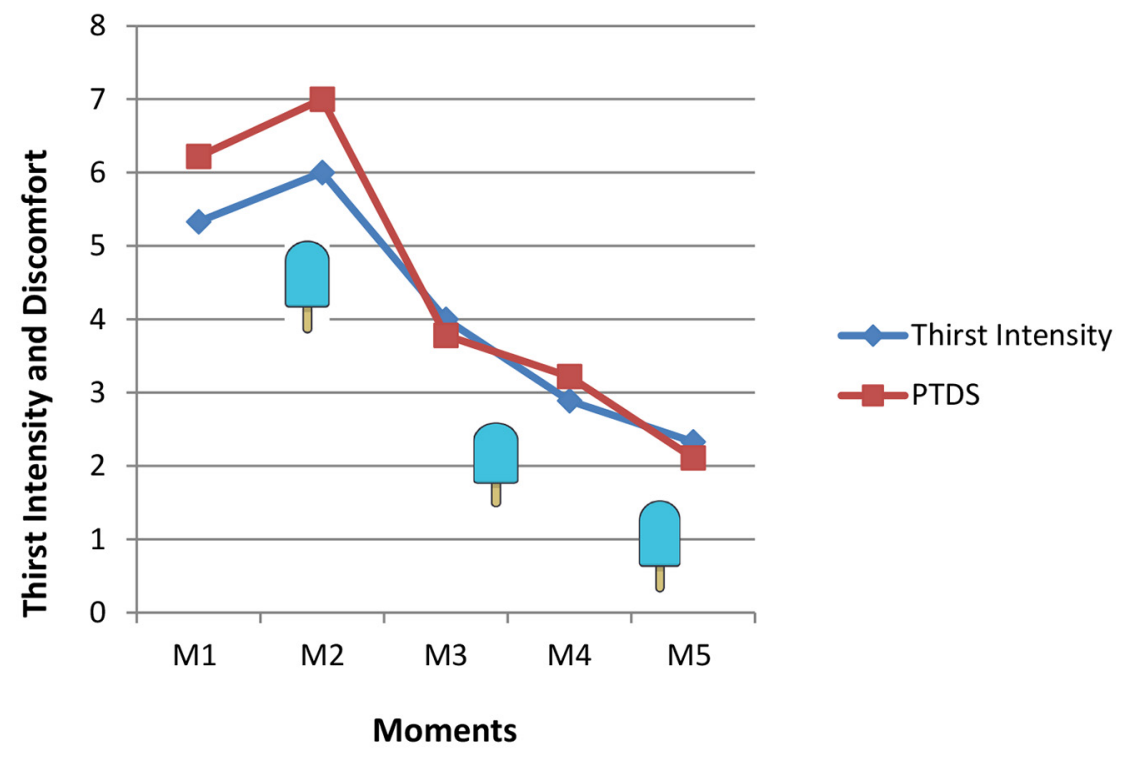

Graph 2 - Variation of the mean thirsty intensity and thirst discomfort (PTDS) during the five assessment moments of the protocol; Londrina, state of Paraná, Brazil, 2018.

Source: The authors.

thirst discomfort at $\mathrm{M} 1$, and a strong positive correlation at $M 2(r=0.77$ and $p=0.01)$.

At $M 3$, thirst intensity and thirst discomfort started to decrease, and there was a weak positive correlation between the variables $(r=0.38$ and $p=0.30)$. The decrease in thirst intensity and discomfort persisted at M4 ( $r=0.45$ and $p=0.021)$ and at M5 ( $r=0.55$ and $p=0.124)$, with a moderate positive correlation. 


\section{DISCUSSION}

This study presents an innovative approach by assessing the physiological profile of AVP after oropharyngeal stimuli provoked by the ice popsicle. This reveals that a cold strategy generates anticipatory inhibition of AVP and of thirst without needing to absorb water through the gastrointestinal tract, since a volume of only $20 \mathrm{ml}$ per popsicle was used. These data are relevant because they show that an easy strategy is able to promote changes in the levels of AVP, a hormone that is intrinsically related both to the homeostatic mechanism of cell fluids and to the perception of thirst intensity and discomfort. Investigating the action of the ice popsicle not only on the subjective perception but also on the thirst hormonal profile will allow for greater reliability in the adoption of this strategy by the health team that provides care to thirsty patients.

AVP is a hormone released into the bloodstream in situations of water deprivation ${ }^{(2)}$. The first thirst stimuli used in the present study was a 12-hour fasting for food and liquids, which resulted in a baseline mean AVP of $5.90 \mathrm{pg} / \mathrm{ml}$ (M1). Considering that the sample was composed of healthy volunteers, it was observed that fasting was sufficient to stimulate AVP secretion, when compared to reference baseline levels found in the literature ${ }^{(2)}$.

AVP is synthesized in the hypothalamic region by supraoptic nuclei and paraventricular nuclei. After its production, AVP is stored in the neurohypophysis and is subsequently released into the bloodstream in the presence of osmolar, volumetric, oropharyngeal, or gastric stimuli, or through angiotensin II ${ }^{(14)}$.

The main stimulation for the release of AVP is increased plasma osmolality. An increase of nearly $1 \mathrm{mOsm} / \mathrm{kg}$ in osmolality triggers the release of 0.4 to $0.8 \mathrm{pg} / \mathrm{ml}$ of AVP into the bloodstream. Plasma AVP concentration at baseline was below $2 \mathrm{pg} / \mathrm{ml}^{(2)}$.

In the present study, we observed that a hypertonic saline solution with a concentration of 2\% increased serum osmolality from $270.65 \mathrm{mOsm} / \mathrm{kg}$ (M1) to $273.53 \mathrm{mOsm} /$ $\mathrm{kg}$ (M2), accounting for an increase of $2.88 \mathrm{mOsm} / \mathrm{kg}$. This increase of nearly $2 \mathrm{mOsm} / \mathrm{kg}$ stimulated the release of $0.4 \mathrm{pg} / \mathrm{ml}$ of AVP, resulting in $7.12 \mathrm{pg} / \mathrm{ml}$ of circulating AVP after the infusion of saline solution and, consequently, in increased plasma osmolality (M2). These findings are thus consistent with the physiological aspects of AVP profile reported in the literature.

Despite not being statistically significant, mean plasma AVP concentrations exhibited visual changes after use of the first ice popsicle. There was a reduction in AVP levels from
$7.12 \mathrm{pg} / \mathrm{ml}$ to $6.41 \mathrm{pg} / \mathrm{ml}$ (M3) and, after the second intervention (M4), AVP levels decreased to $5.80 \mathrm{pg} / \mathrm{ml}$. However, AVP levels exhibited an atypical behavior at M5, because they increased again to $6.63 \mathrm{pg} / \mathrm{ml}$, even after receiving the last intervention. At this moment, plasma osmolality increased to $285.51 \mathrm{mOsm} / \mathrm{kg}$.

A similar result was found in a study which subjected four healthy volunteers to dehydration using dry food and fasting of fluids for 24 hours before the beginning of the study protocol. After this period, the participants were allowed to suck on ice chips for 30 minutes, with a total volume not exceeding $100 \mathrm{ml}$. There was a decrease in AVP levels promptly within 10 minutes of the protocol, from $2.8 \mathrm{pg} /$ $\mathrm{ml}$ to $1.8 \mathrm{pg} / \mathrm{ml}$. The study concluded that oropharyngeal stimuli triggered by ice chips were sufficient to change AVP levels. However, when the volunteers received a hypertonic infusion, the osmotic stimuli surpassed those triggered by cold in the oral cavity ${ }^{(15)}$. A similar event is observed in this study, because the continuous increase in osmolality with no correction of fluids with large volumes increased AVP levels at M5.

The reduction in the hormonal profile of AVP can be explained by the presence of oropharyngeal receptors sensitive to osmolality (osmoreceptors), pressure (mechanoreceptors) and temperature (thermoreceptors) of liquids in the oral cavity. These receptors are one of the main anticipatory mechanisms involved in thirst inhibition ${ }^{(7,16-17)}$ and transmit information received in the oral cavity to cortical and limbic areas, such as cingulate cortex, orbitofrontal cortex, and hypothalamus ${ }^{(6,18)}$. Thus, it is possible to generate, in the body, a satiety process independent from the correction of serum osmolality ${ }^{(1,7,19)}$.

Considering that the variables were controlled and did not undergo environmental changes, it can be hypothesized that the reduction in AVP levels after $M 2$ resulted from oropharyngeal stimuli triggered by the ice popsicle. Furthermore, the strategy is believed to have a transient effect leading to reduced AVP via central receptors, since serum osmolality continued to increase during the development of the protocol.

Randomized clinical trials conducted with surgical patients at the Post Anesthetic Recovery Room and during the preoperative period showed a statistically significant reduction in thirst intensity and discomfort with use of the ice popsicle ${ }^{(9)}$. Therefore, it is possible to associate subjective measures of thirst with AVP concentration and plasma osmolality. This can be discussed based on a study aimed at estimating plasma AVP and serum osmolality using thirst perception, by means of the visual analog scale (VAS). The 
results of the study showed that there is a direct relationship between the values of thirst perception and serum osmolality, so as to calculate plasma AVP(10).

Thirst intensity and discomfort were significantly reduced after all the interventions. This finding may be justified by the effectiveness of cold compounds in reducing thirst ${ }^{(9)}$, resulting from their involvement in anticipatory mechanisms ${ }^{(1)}$.

The effect of the ice popsicle on thirst intensity and discomfort leads to a refreshing sensation, providing a pleasant and pleasurable experience. Moreover, the use of cold strategies stimulates the production of saliva and increase lip hydration ${ }^{(7)}$, which promotes a decrease in AVP release within few minutes ${ }^{(17)}$.

Hence, the genesis of thirst is closely related to increased osmolality, but the anticipatory mechanisms determine thirst satiety much earlier before total correction of the serum osmolality levels. Previous studies observed that the activity of the subfornical organ neurons present in the lamina terminalis, which are responsible for detecting plasma osmolality, was inhibited within a minute only due to the presence of cold water in the oral cavity ${ }^{(20)}$.

In the present study, it is observed that plasma osmolality increases while urine osmolality decreases. Sodium ( $\mathrm{Na}+$ ) is the main solute involved in the control of osmotic pressure. Increased extracellular $\mathrm{Na}+$ moves water out of the cell until there is a balance between the intra- and extra-cellular osmotic pressures. Maintaining osmolality between fluids allows human beings to maintain hydration ${ }^{(2)}$.

It was chosen to use urine osmolality levels to observe their behavior in relation to serum osmolality, in the presence of liquid restriction and stimulation for AVP secretion. In the clinical practice, the presence of AVP can be inferred by the urinary concentration of solutes and its consequent presence in plasma. This finding reinforces the study hypothesis that there is a reduction in the AVP as a result of oropharyngeal stimuli and not from reduced plasma osmolality, since decreased AVP levels were accompanied by decreased urine osmolality.

In short, it is hypothesized that the ice popsicle stimulates the oropharyngeal cavity and thus acts in the anticipatory mechanisms that trigger stimuli at the central level, leading both to a decrease in thirst intensity and discomfort and to a transient hormonal inhibition of vasopressin. Decreased AVP levels cannot be attributed to the post-absorptive mechanism, since there was no correction of plasma osmolality with use of the ice popsicle, due to its low volume.

It is necessary to develop new laboratory clinical studies, so as to elucidate the hormonal behavior of the individuals experiencing thirst, especially chronic, surgical, and serious patients, and to fill the existing gaps with regard to the satiety process. Understanding the hormonal activity involved in the thirst mechanism allows for the health teams to choose effective strategies to alleviate this discomfort.

The limitations of the present study are related to its sample size and to the need for comparing the behavior of these variables with that of the variables obtained from a control group. Thus, it is recommended to conduct new studies that compare the hormonal profile of AVP, as well as of angiotensin II, among individuals who received ice popsicles in relation to fasting.

\section{CONCLUSION}

There was a reduction in thirst intensity and discomfort after the use of the ice popsicle. There was no statistical difference for decreased AVP and increased osmolality between the study moments. However, there was a reduction in the hormonal physiological profile of AVP when the volunteers received treatment, during the first 30 minutes of intervention.

\section{REFERENCES}

1. Zimmerman $C A$, Leib $D E$, Knight ZA. Neural circuits underlying thirst and fluid homeostasis. Nat Rev Neurosci. 2017;18(8):459-69. doi: https://doi. org/10.1038/nrn.2017.71

2. Aloamaka EO, Amabebe E, Ozoene J0, Obika LFO. Thirst perception, drinking, arginine vasopressin activity and associated neurohumoral factors. J Afr Assoc Physiol Sci. 2018 [cited 2019 Sep 12];6(1):1-13. Available from: https://www. ajol.info/index.php/jaaps/article/view/175955

3. Arai SR, Butzlaff A, Stotts NA, Puntillo KA. Quench the thirst: lessons from clinical thirst trials. Biol Res Nurs. 2014;16(4):456-66. doi: https://doi. org/10.1177/1099800413505900

4. Silva LCR, Aroni P, Fonseca LF. I am thirsty! Experience of the surgical patient in the perioperative period. Rev SOBECC. 2016;21(2):75-81. doi: https://doi. org/10.5327/Z1414-4425201600020003

5. Aguilar-Nascimento JE, Dias ALA, Dock-Nascimento DB, Correia MITD, Campos $A C L$, Portari-Filho PE, et al. Actual preoperative fasting time in Brazilian hospitals: the BIGFAST multicenter study. Ther Clin Risk Manag. 2014;10:10712. doi: https://doi.org/10.2147/TCRM.S56255

6. Saker P, Farrel MJ, Adib FRM, Egan GF, McKinley MJ, Denton DA. Regional brain responses associated with drinking water during thirst and after its satiation. Proc Natl Acad Sci. 2014;111(14):5379-84. doi: https://doi.org/10.1073/ pnas. 1403382111

7. Eccles R, Du-Plessis L, Dommels Y, Wilkinson JE. Cold pleasure: why we like ice drinks, ice-Iollies and ice cream. Appetite. 2013;71:357-60. doi: https://doi. org/10.1016/j.appet.2013.09.011

8. Gizowski C, Bourque $(W$. The neural basis of homeostatic and anticipatory thirst. Nature Rev Nephrol. 2018;14(1):11-25. doi: https://doi.org/10.1038/ nrneph.2017.149 
9. Conchon MF, Fonseca LF. Efficacy of an ice popsicle on thirst management in the immediate postoperative period: a randomized clinical trial. J Perianesth Nurs. 2018;33(2):153-61. doi: https://doi.org/10.1016/j.jopan.2016.03.009

10. Obika LFO, Ozoene J0. Estimation of plasma arginine vasopressin concentration using thirst perception and plasma osmolality values. Niger J Physiol Sci. 2014 [cited Sep 22];29(2):119-24. Available from: https://www.ajol.info/index.php/ njps/article/view/122253/111735

11. Stevenson RJ, Mahmut M, Rooney K. Individual differences in the interoceptive states of hunger, fullness and thirst. Appetite. 2015;95:44-57. doi: https://doi. org/10.1016/j.appet.2015.06.008

12. Gries K, Berry P, Harrington M, Crescioni M, Patel M, Rudell K, et al. Literature review to assemble the evidence for response scales used in patient reported outcome measures. J Patient Rep Outcome.2018;2:41. doi: https://doi. org/10.1186/s41687-018-0056-3

13. Martins PR, Fonseca LF, Rosseto EG, Mai LD. Developing and validating the Perioperative Thirst Discomfort Scale. Rev Esc Enferm USP. 2017;51:e03240. doi: https://doi.org/10.1590/s1980-220×2016029003240

14. Bichet DG. Vasopressin and the regulation of thirst. Ann Nutr Metab. 2018;72(2):3-7. doi: https://doi.org/10.1159/000488233

\section{- Funding:}

Araucária Foundation/Coordination for the Improvement of Higher Level Personnel (Coordenação de Aperfeiçoamento de Pessoal de Nível Superior, CAPES).

\section{- Corresponding author:}

Thammy Gonçalves Nakaya

E-mail: thammynakaya@hotmail.com
15. Salata RA, Verbalis JG, Robinson AG. Cold water stimulation of oropharyngeal receptors in man inhibits release of vasopressina. J Clin Endocrinol Metabol. 1987;65(3):561-7. doi: https://doi.org/10.1210/jcem-65-3-561

16. Gizowski C, Bourque $(W$. Neurons that drive and quench thirst. Science. 2017;357(6356):1092-3. doi: https://doi.org/10.1126/science.aa05574

17. Leib DE, Zimmerman CA, Poormoghaddam A, Huey EL, Ahn JS, Lin Y, et al. The forebrain thirst circuit drives drinking through negative reinforcement. Neuron. 2017;96(6):1272-81.e4. doi: https://doi.org/10.1016/j. neuron.2017.11.041

18. Armstrong LE, Kavouras SA. Thirst and drinking paradigms: evolution from single factor effects to brainwide dynamic networks. Nutrients. 2019;11(2864). doi: https://doi.org/10.3390/nu11122864

19. Denton D, Shade R, Zamarippa F, Egan G, Blair-West J, McKinley M, et al. Neuroimaging of genesis and satiation of thirst and an interoceptor-driven theory of origins of primary consciousness. Proc Natl Acad Sci. 1999;96(9):53049. doi: https://doi.org/10.1073/pnas.96.9.5304

20. Zimmerman CA, Lin Y-C, Leib DE, Guo L, Huey EL, Daly GE. Thirst neurons antecipate the homeostatic consequences os eating and drinking. Nature. 2016;29;537(7622):680-4. doi: https://doi.org/10.1038/nature18950

\section{Associate editor:}

